OPEN ACCESS

Edited by:

Kanwaljeet J. S. Anand, Stanford University,

United States

Reviewed by:

Lokesh Tiwari,

All India Institute of Medical

Sciences, Patna, India

Arun Saini,

University of Tennessee

Health Science Center,

United States

*Correspondence:

Dayanand Bagdure

dbagdure@som.umaryland.edu

Specialty section:

This article was submitted to Pediatric Critical Care,

a section of the journal

Frontiers in Pediatrics

Received: 04 April 2017 Accepted: 06 November 2017 Published: 24 November 2017

Citation:

Remy KE, Custer JW, Cappell J, Foster CB, Garber NA, Walker LK, Simon L and Bagdure D (2017) Pediatric Anti-N-Methyl-D-Aspartate Receptor Encephalitis: A Review with Pooled Analysis and Critical Care Emphasis.

Front. Pediatr. 5:250

doi: 10.3389/fped.2017.00250

\section{Pediatric Anti-N-Methyl-D-Aspartate Receptor Encephalitis: A Review with Pooled Analysis and Critical Care Emphasis}

Kenneth E. Remy $y^{1,2,3}$, Jason W. Custer ${ }^{1}$, Joshua Cappell ${ }^{4}$, Cortney B. Foster ${ }^{1}$, Nan A. Garber ${ }^{1}$, L. Kyle Walker ${ }^{1}$, Liliana Simon ${ }^{1}$ and Dayanand Bagdure ${ }^{1 *}$

'Division of Pediatric Critical Care Medicine, Department of Pediatrics, University of Maryland School of Medicine, Baltimore, MD, United States, ${ }^{2}$ Critical Care Medicine Department, Clinical Center, The National Institutes of Health, Bethesda, MD, United States, ${ }^{3}$ Division of Pediatric Critical Care, Department of Pediatrics, Washington University School of Medicine, St. Louis, MO, United States, ${ }^{4}$ Divisions of Pediatric Neurology and Critical Care, Departments of Neurology and Pediatrics, Morgan Stanley Children's Hospital, Columbia University College of Physicians and Surgeons, New York, NY, United States

Purpose: Anti- $N$-methyl-D-aspartate receptor (NMDAR) encephalitis is being recognized with increasing frequency among children. Given the paucity of evidence to guide the critical care management of these complex patients, we provide a comprehensive review of the literature with pooled analysis of published case reports and case series.

Methods: We performed a comprehensive literature search using PubMed, Scopus, EMBASE, and Web of Science for relevant published studies. The literature search was conducted using the terms NMDA, anti-NMDA, Anti- $N$-methyl-D-aspartate, pediatric encephalitis, and anti-NMDAR and included articles published between 2005 and May 1, 2016.

Results: Forty-eight references met inclusion criteria accounting for 373 cases. For first-line treatments, 335 (89.8\%) received high-dose corticosteroids, 296 received intravenous immunoglobulin (79.3\%), and 116 (31\%) received therapeutic plasma exchange. In these, 187 children (50.1\%) had a full recovery with only minor deficits, 174 patients (46.7\%) had partial recovery with major deficits, and 12 children died. In addition, 14 patients were reported to require mechanical ventilation.

Conclusion: Anti-NMDA encephalitis is a formidable disease with great variation in clinical presentation and response to treatment. With early recognition of this second most common cause of pediatric encephalitis, a multidisciplinary approach by physicians may provide earlier access to first- and second-line therapies. Future studies are needed to examine the efficacy of these current therapeutic strategies on long-term morbidity.

Keywords: $\mathrm{N}$-methyl-D-aspartate receptor, $\mathrm{N}$-methyl-D-aspartate, encephalitis, autoimmune, critical care, pediatrics, paraneoplastic

Abbreviations: CT, Cat scan; CNS, central nervous system; CPR, cardiopulmonary resuscitation; CSF, cerebrospinal fluid; EEG, electroencephalogram; IVIG, intravenous immunoglobulin; MRI, magnetic resonance imaging; NMDAR, $N$-methyl-Daspartate receptor; PICU, pediatric intensive care unit. 


\section{INTRODUCTION}

Pediatric critical care physicians are increasingly called upon to diagnose, manage, and treat children with anti- $N$-methylD-aspartate receptor (anti-NMDAR) encephalitis. Anti-NMDAR encephalitis was originally described in 2005 in four women with ovarian teratomas, presenting with seizures, acute psychiatric disturbances, cognitive deficits, decreased sensorium, autonomic instability, and hypoventilation (1). Dalmau et al. in 2007 diagnosed these women and eight others after demonstrating specific autoantibodies to the NMDAR; namely, a neuronal cell surface protein that was shown to be the NR1 subunit of the receptor (2).

Since the first reported cases and discovery of anti-NMDAR encephalitis, this disease has surpassed all single viral etiologies and has been recognized as the second most common entity after the mixed disturbance encephalomyelitis, acute demyelinating encephalitis $(2,3)$. The estimated mortality for anti-NMDAR encephalitis in one series of 100 adults with a median age of 23 years was 4\% (4). Although over 600 adult and pediatric cases have been reported in the literature with 2 case series of 15 patients and 77 patients among critically ill adults, further critical care-focused considerations have been lacking (5-12). Nonetheless, some authors have suggested that earlier treatment in children may result in better outcomes (13-15). We reviewed the literature to evaluate the use of corticosteroids and intravenous immunoglobulin (IVIG) as a first-line therapy for patients with anti-NMDAR encephalitis. Next, we provide a pooled analysis of reviewed data and critical care considerations based on literature review for critically ill children with anti-NMDAR encephalitis.

\section{MATERIALS AND METHODS}

We conducted a search of PubMed, Scopus, EMBASE, and Web of Science to identify relevant published studies and abstracts and then conducted a systematic, narrative review of potentially relevant sources. The literature search was conducted using the terms NMDA, anti-NMDA, anti-NMDAR, pediatric encephalitis, and anti-NMDAR and included articles published between January 1, 2005, and May 1, 2016. Furthermore, the search was limited to "humans," children, and abstracts or reports published in English, and screening was performed by the first author (Kenneth E. Remy). Our search criteria are included in the supplemental information. Inclusion criteria were any clinical study or report in which subjects (1) demonstrated anti-NMDA receptor encephalitis by positive serum and/or cerebrospinal fluid (CSF) anti-NMDAR and (2) were younger than 19 years (intended age, 0-18 years). Exclusion criteria included (1) the absence of a laboratory data to support the diagnosis, i.e., no evidence of serum and/or CSF NMDAR antibodies; (2) adults older than 18 years; or (3) publications not in English. Since the majority of this information was individual case reports, this information was combined and tabulated to document current practice. The variables collected included age; sex; presence of positive CSF or blood anti-NMDA receptor titers; use of first-line therapies including high-dose corticosteroids, IVIG, or plasma exchange; use of second-line therapies such as rituximab or cyclophosphamide; and need for mechanical ventilation. Outcome measures were modified from previous studies and classified as complete recovery with only mild deficit, partial recovery with significant deficit, and death $(8,16)$. One of the authors (Kenneth E. Remy) retrospectively assigned all patients to one of these outcome groups. As this review was performed on published reports and lacked patient identifying data, the University of Maryland Institutional Review Board waived the need for approval.

\section{RESULTS}

The search identified 862 potentially relevant studies, and 201 were selected for data extraction. From these, 48 references met inclusion criteria, including 27 individual case reports and 21 case series (Figure 1) $(4,10-12,14,15,17-57)$. Two prospective cohort studies were found $(45,53)$. One large retrospective cohort series accounted for 211 patients (14). The presence of both clinical diversity and methodological diversity precluded combining the study reports in a meta-analysis. Whenever possible, authors were electronically mailed for missing data.

A total of 382 patients were included; however, incomplete data were included in the case reports for 9 patients. Thus, 373 patients with a mean age of 9.98 years (range, 3 months- 18 years) were included in our pooled data analysis presented in Table 1. Larger case series that included only means and range of ages precluded calculation of SD of mean age. The pooled analysis included 254 females (68.1\%) and 119 (31.9\%) males (9 reports did not include sex). Subjects represented nine different countries. Sixty-five of 66 patients with evidence of teratoma (17.6\%) were females, as described in the original case reports (1). Anti-NMDA titers were positive in the CSF and serum of 327 (87.6\%) and $276(74 \%)$ patients, respectively.

For first-line treatments (as reported as first agent given or delineated in report), $335(89.8 \%)$ received high-dose corticosteroids, 296 received IVIG (79.3\%), and 116 (31\%) received therapeutic plasma exchange. Five patients received electroconvulsive therapy (ECT) $(34,46,50-52)$, and 14 children required mechanical ventilation $(11,12,22,28,37,38,42,44,52,53,55,56)$. There were five reports that explicitly defined the use of intensive care or pediatric intensive care unit although some reports alluded to need for "advanced" therapies $(30,34,38,54,55)$. In reported outcomes, 187 children $(50.1 \%)$ had a full recovery with only minor deficits, while 174 patients $(46.7 \%)$ had partial recovery with major deficits at 1-year follow-up. Twelve children (3.2\%) died subsequent to their disease.

To best define the use of first- and second-line therapies, we next examined the reports that provided delineation between initiations of specific therapies. In 15 reports of 20 patients that defined a time period before first agent and initiation of second agent, 13 patients received high corticosteroids administered on mean day $8.71(\mathrm{SD} \pm 3.2)$ and 7 patients received IVIG on mean day $7.57(S D \pm 7.7)(19,21,25,27-30,32,36,37,41,42,49$, $50,58)$. The mean time course from reported first agent to second in these 15 reports was 11.4 days $(S D \pm 15.6)$. Second-line therapies included rituximab in 87 patients $(23.3 \%)$ and cyclophosphamide 62 patients (16.6\%). In this cohort of 15 reports ( $n=19$ patients), clinical duration of symptoms began $31.3 \pm 20.1$ days prior to admission (range, 1-90 days). Time to complete resolution 


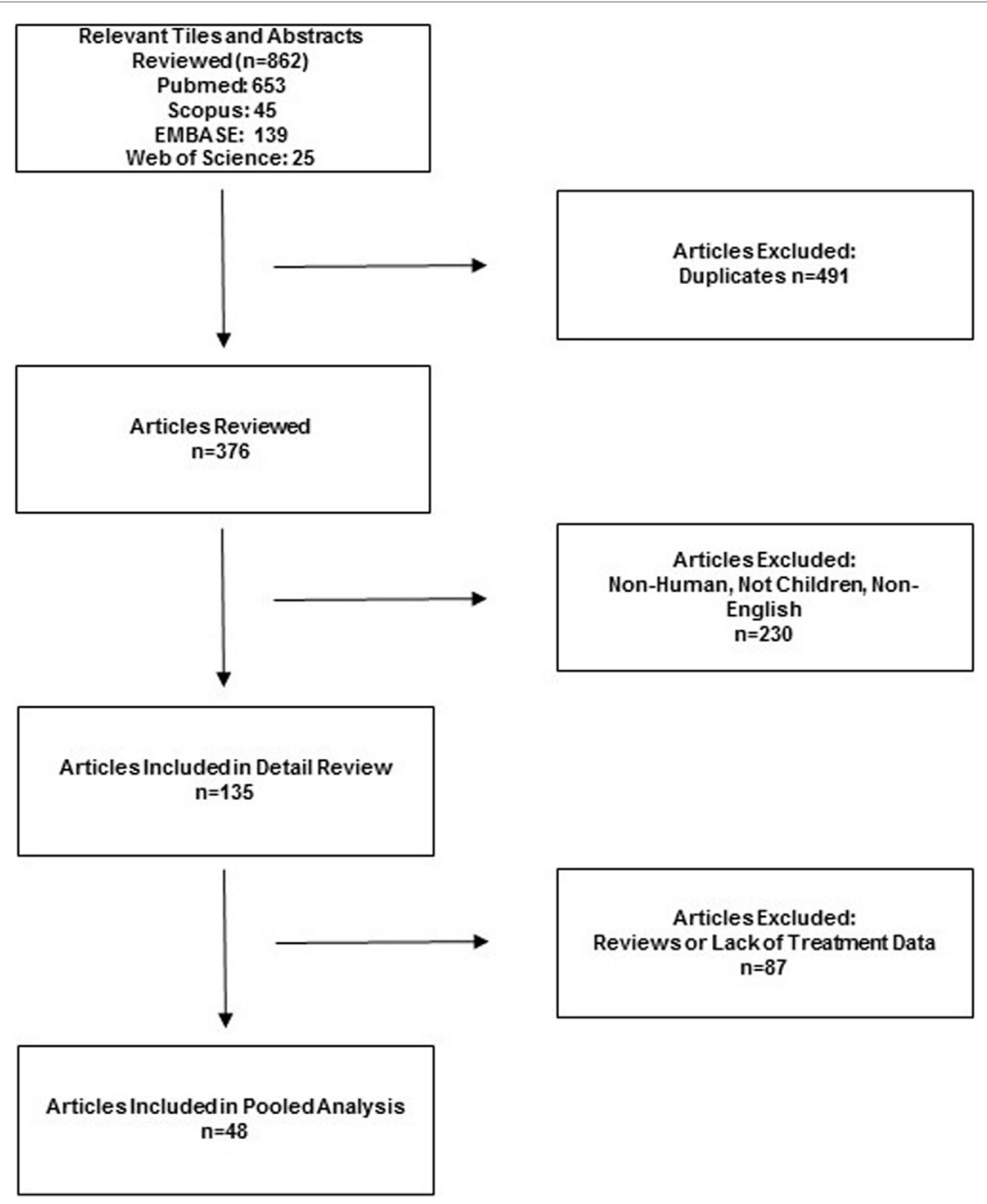

FIGURE 1 | Flow diagram of the published articles evaluated for inclusion in pooled analysis.

of symptoms was $115.6 \pm 86$ days (range, $21-279$ days; $n=15$ patients), and four patients did not have complete resolution.

\section{DISCUSSION}

We pooled data from all relevant case reports, case series, and available retrospective cohort studies to better characterize the disease epidemiology, treatment modalities, and clinical outcomes of children with anti-NMDAR encephalitis.

\section{Epidemiology}

Anti- $N$-methyl-D-aspartate receptor encephalitis affects both males and females, with a higher incidence among females $(75 \%$ cases) $(8,32,52,59-62)$. Although it was originally described as a paraneoplastic disease with $58 \%$ patients showing evidence of an underlying tumor (most commonly ovarian teratoma), published literature reports only 31 and $9 \%$ of children younger than 18 years and younger than 14 years, respectively, had evidence of tumor $(8,16)$. As non-Caucasians have a higher incidence of ovarian teratomas, they also have higher incidence of anti-NMDAR encephalitis $(32,59)$. This association has been described in children as young as 3 months of age; however, most of the reported cases are adolescents $(21,61,63,64)$. In our pooled analysis, we have identified similar findings to those reported previously, with almost $70 \%$ of cases being female, an average age of 10 years, and $18 \%$ patients having a teratoma.

Despite these data, the diagnosis of anti-NMDAR encephalitis is still uncommon with many cases designated as idiopathic and possible or probable. Only 79 patients had identifiable diagnoses in the California Encephalitis Project of 761 cases, with 32 children having anti-NMDAR encephalitis (4.2\%) and 30 children with enteroviral encephalitis (3.9\%). Within this cohort, DuBray et al. described that $11 \%$ of children with encephalitis at her single center (compared to the entire centers in the project) occurred secondary to Mycoplasma infection, with a slightly lower incidence of $3.6 \%$ resulting from anti-NMDAR antibodies (65). Of interest, one-half of the cases with idiopathic psychiatric symptoms had antibodies against $\operatorname{NMDAR}(3,22)$. This raises 
TABLE 1 | Pooled analysis.

\begin{tabular}{ll}
\hline Total patients & 373 children \\
Sex & $254 \mathrm{~F}(68.1 \%) 119 \mathrm{M}(31.9 \%)$ \\
Mean age & 9.98 years (range, 3-18 years) \\
Teratoma or malignancy present & $66(17.6 \%)$ \\
CSF positive for anti-NMDAR & $327(87.6 \%)$ \\
Serum positive for anti-NMDAR & $276(74 \%)$ \\
First-line treatments & \\
High-dose corticosteroids & $335(89.8 \%)$ \\
Intravenous immunoglobulin & $296(79.3 \%)$ \\
Plasma exchange & $116(31 \%)$ \\
Second-line treatments & \\
Rituximab & $87(23.3 \%)$ \\
Cyclophosphamide & $62(16.6 \%)$ \\
Third-line treatments & \\
Electroconvulsive therapy & $5(1.3 \%)$ \\
Mechanical ventilation & $14(3.8 \%)$ \\
Outcomes & \\
Complete recovery with minor deficits & $187(50.1 \%)$ \\
Partial recovery with major deficits & $174(46.7 \%)$ \\
Death & $12(3.2 \%)$ \\
\hline
\end{tabular}

the question whether children with postinfectious encephalitis (i.e., HSV and Mycoplasma) and without tumor develop antiNMDAR antibodies as parts of a larger, nonspecific immune response to these pathogens. The inciting infection may trigger antibodies directed against NMDAR, and thus, unusual presentations of viral encephalitis should be screened for concomitant autoimmune encephalitis $(17,42)$. Awareness of this disease and the availability of diagnostic molecular tests may improve our ability to diagnose the underlying etiologies of pediatric encephalitides.

\section{Clinical Course}

Some authors have described anti-NMDAR encephalitis as having three clinical stages; a prodromal stage, an early (psychotic and/or seizure phase), and a late (hyperkinetic) phase $(62,66)$. Most interestingly, serum and CSF antibody titers seem to correlate with the disease course: a decline in titers coincides with improvement in symptoms (16). In the prodromal stage, symptoms include fever, nausea, vomiting, or upper respiratory tract infection-like symptoms $(4,22,31,67)$. This prodrome may last up to 2 weeks in $70 \%$ of patients $(2,31)$. During the early stage, patients may develop psychiatric symptoms such as fear, delusions, mania, and/or paranoia-manifesting in children as behavioral disturbances and tantrums rather than an underlying pathologic process. Children are more likely than adults to present with seizures, dystonia, or status epilepticus (11). Within 3-4 weeks, a more fulminant stage develops. Rapid disintegration of speech and language, hyperactivity, mutism, and irritability are often seen. Progression to decreased responsiveness, catatonia, autonomic instability, cardiac arrhythmias, hypoventilation, and uncoordinated respiration can lead to rapid deterioration and need for critical care interventions. Autonomic dysregulation and hypoventilation are less common in children than adults, while speech dysfunction appears more frequently $(22,68)$. During treatment, recovery has been described as reversal of symptoms in the reverse order of presentation (16).
TABLE 2 | Proposed therapies for anti-NMDAR encephalitis.

\begin{tabular}{|c|c|}
\hline $\begin{array}{l}\text { First-line therapies (if tumor is } \\
\text { present, begin after removal) }\end{array}$ & $\begin{array}{l}\text { Second-line therapies (if disease is } \\
\text { refractory after } 10 \text { days) }\end{array}$ \\
\hline $\begin{array}{l}\text { IVIG } 0.4 \mathrm{~g} / \mathrm{kg} \text { for } 5 \text { days and } \\
\text { methylprednisolone } 30 \mathrm{mg} / \mathrm{kg} \text { daily for } \\
5 \text { days or plasma exchange daily for } \\
\text { six cycles }\end{array}$ & $\begin{array}{l}\text { Rituximab } 375 \mathrm{mg} / \mathrm{m}^{2} \text { weekly for } \\
4 \text { weeks and cyclophosphamide } \\
750 \mathrm{mg} / \mathrm{m}^{2} \text { monthly (duration is based } \\
\text { on clinical improvement) }\end{array}$ \\
\hline
\end{tabular}

\section{Diagnostic Evaluation}

Once clinical suspicion is raised, all patients presenting with encephalitis should be evaluated for anti-NMDAR antibodies and receive imaging studies to exclude the presence of a teratoma $(62,69)$. Definitive diagnosis is made by CSF evidence of anti-NMDAR antibodies. CSF studies usually demonstrate an elevated white blood cell count, lymphocytic pleocytosis in $87 \%$ of children, and oligoclonal bands in $60 \%$ of patients $(16,31,69)$. In our analysis, most patients had positive serum and/or CSF antibodies to NMDAR. However, one must interpret our findings with caution as reporting bias may falsely elevate positive results. While examining for anti-NMDAR encephalitis, one should also consider other encephalitides including AMPA-R, metabotropic glutamate receptor, voltage-gated potassium channels (LGI1, CASPR2, or contactin-2), anti-Hu, anti-CV2, anti-CRM, anti-P5, anti-MA proteins, voltage-gated calcium channel defects, $G_{A B A}{ }^{B}-R$, glycine- $R$, and $G A B A^{A}-R$ defects $(53,70,71)$.

\section{Clinical Management}

When there is high clinical suspicion for the disease, rapid treatment should occur in a stepwise fashion as confirmatory testing is not performed at some centers and may take days to weeks $(62,66)$. The known pathophysiology and current (low-grade) evidence suggests that starting therapy earlier may lead to better outcomes. With appropriate treatment, substantial improvement or complete recovery can occur in up to $75 \%$ of patients $(4,14)$. However, relapses may occur in approximately $25 \%$ of children even after resolution (8). Surgical removal of a teratoma or other tumor is necessary but should not delay initiation of definitive therapy. In our small cohort of reports that defined clinical symptom time course of presentation and resolution after treatment, there was great variation among different aged patients and response to therapies. This makes generalizations of presentation and treatment findings difficult to assess. However, from current evidence, first-line therapies have included plasma exchange, IVIG, or high-dose corticosteroids. Based on all available information, it seems that IVIG therapy with $0.4 \mathrm{~g} / \mathrm{kg}$ daily for 5 days or $1 \mathrm{~g} / \mathrm{kg}$ on day 1 followed by $0.5 \mathrm{~g} / \mathrm{kg} /$ day for 2 additional days and methylprednisolone $1 \mathrm{~g}$ (adults) or $30 \mathrm{mg} / \mathrm{kg}$ (children up to $40 \mathrm{~kg}$ ) daily for 3 days or daily plasma exchange for six cycles would likely have favorable clinical effects (Table 2). In refractory cases or critically ill patients, second-line immunomodulation with rituximab or cyclophosphamide may be attempted $(2,4,8$, 27,31). In adults and children, combined second-line therapies of rituximab $375 \mathrm{mg} / \mathrm{m}^{2}$ weekly for 4 weeks and cyclophosphamide $750 \mathrm{mg} / \mathrm{m}^{2}$ monthly have been proposed $(27,51)$. After therapy 
is completed, some authors recommend yearly screening with pelvic magnetic resonance imaging to assess for ovarian tumors $(8,32,69)$. Details of critical care management for individual patients were unavailable for us to define treatment benefit with individual treatment approaches. Future prospective studies should evaluate the need and indications for ICU admission, duration of ICU care, complications associated with the disease and/or treatments, and evaluation of all-cause mortality among patients with this disease.

\section{Critical Care Considerations}

Children with significant neurological symptoms should be initially managed in an ICU as autonomic dysfunction, airway protection, hypoventilation, cardiac arrhythmia, or hyperkinetic crisis may occur. Pediatric critical care requires an interdisciplinary team including neurologists, psychiatrists, cardiologists, nutritionists, physical therapists, social workers, physiatrists, pastoral care, and child life experts. Symptom-guided therapies are listed in Table 3.

There are two main variations of instability that require critical care management: a neurologic type with catatonic or hyperkinetic crises and one that manifests with autonomic and hemodynamic instability $(10,27,50)$. Although $84 \%$ of children have hyperkinetic movements, the literature is lacking in effective therapies (8). Valproic acid, gabapentin, and lithium have been used for mood dysregulation $(25,28,31,72)$. Clonidine, trazodone, and benzodiazepines target sleep cycle dysregulation, and phenobarbital, trihexyphenidyl (Artane ${ }^{\mathrm{TM}}$ ), and opioids are used for extreme agitation $(10,25,28,30,38,50)$. For catatonia, benzodiazepines or rarely ECTs have been reported $(8,16,51$, $73,74)$. Routine management of agitation may include low-dose opioids, other sedatives, anxiolytics, or anti-psychotic drugs. For refractory agitation, methotrimeprazine or dexmedetomidine

TABLE 3 | Intensive care symptom-guided therapies.

\begin{tabular}{|c|c|c|c|}
\hline Symptoms & First-line therapy & $\begin{array}{l}\text { Second-line } \\
\text { therapy }\end{array}$ & $\begin{array}{l}\text { Refractory } \\
\text { therapy }\end{array}$ \\
\hline Agitation & $\begin{array}{l}\text { Trihexyphenidyl } \\
(0.02-0.06 \mathrm{mg} / \mathrm{kg} \\
\text { or } 1 \mathrm{mg} 1-2 \text { times } \\
\text { daily) and low-dose } \\
\text { opioids (fentanyl } 1 \\
\mu \mathrm{g} / \mathrm{kg} / \mathrm{h} \text { infusion or } \\
\text { bolus) }\end{array}$ & $\begin{array}{l}\text { Dexmedetomidine } \\
\text { infusion }(0.2 \mu \mathrm{g}-1.5 \\
\mu \mathrm{g} / \mathrm{kg} / \mathrm{min})\end{array}$ & $\begin{array}{l}\text { Propofol infusion } \\
(10-30 \mu \mathrm{g} / \mathrm{kg} / \mathrm{min})\end{array}$ \\
\hline $\begin{array}{l}\text { Catatonia } \\
\text { autonomic } \\
\text { dysfunction } \\
\text { bradycardia }\end{array}$ & $\begin{array}{l}\text { Glycopyrrolate } \\
(0.004-0.01 \mathrm{mg} / \\
\text { kg q4-8 h prn: } \\
\text { maximum, } \\
0.1-0.2 \mathrm{mg} / \text { dose, } \\
0.8 \mathrm{mg} / \text { day) }\end{array}$ & $\begin{array}{l}\text { Theophylline (begin } \\
\text { oral } 300 \mathrm{mg} / \text { day } \\
\text { divided q4-6 h up } \\
\text { to a maximum dose } \\
600 \mathrm{mg} / 24 \mathrm{~h} \text { ) }\end{array}$ & $\begin{array}{l}\text { Electroconvulsive } \\
\text { therapy }\end{array}$ \\
\hline Hypoventilation & & & $\begin{array}{l}\text { Tracheostomy } \\
\text { (if ventilated for } \\
>4 \text { weeks) }\end{array}$ \\
\hline $\begin{array}{l}\text { Additional } \\
\text { considerations }\end{array}$ & & & $\begin{array}{l}\text { Gastric-tube } \\
\text { placement } \\
\text { Early physical } \\
\text { therapy }\end{array}$ \\
\hline
\end{tabular}

infusion may be beneficial for both intubated and non-intubated patients. For continued refractory symptoms, mechanical ventilation and low-dose propofol or ketamine infusions may be beneficial, although used with extreme caution. Careful attention and laboratory surveillance are needed to avoid propofol infusion syndrome, especially for children younger than 5 years and those receiving propofol for longer than 24 hours (75-78). Barbiturates and dexmedetomidine should be used at the lowest possible dosing to avoid bradycardia. Non-pharmacological therapies (noise reduction, adjusting room ambiance) should be employed to avoid agitation. Finally, muscle relaxants should be avoided to avoid ICU myopathies, especially with concomitant corticosteroid therapy (79).

The autonomic and hemodynamic instability can be difficult to manage. Resting tachycardia is widely reported in multiple case studies of pediatric patients $(4,8,11)$. However, severe bradycardia and asystole events may be exacerbated by vagal stimulation including endotracheal tube suctioning or bowel movements $(36,80)$. Foley catheter use, bowel regimens to prevent constipation, and careful suctioning of the endotracheal tube are essential to minimize parasympathetic stimulation. Bradycardia events were also associated with seizures in this patient population and continuous electroencephalogram should be considered to capture these events (81).

Chronic use of medications such as glycopyrrolate or theophylline may be considered for preventing severe bradycardia; these medications have been successful in other disease processes to prevent symptomatic bradycardia (82). If severe bradycardia is frequent and unresponsive to medical therapies, an implantable pacemaker may be considered (83). Brain imaging to diagnose hydrocephalus may be indicated with new onset of bradycardia events in some patients (69).

Autonomic dysfunction also manifests as impaired temperature or blood pressure regulation. While patients are maintained on immunosuppressant therapies, infectious etiologies for hypothermia/hyperthermia must be considered. We have observed that movement disorders are often exacerbated during the febrile state; aggressive temperature control should be implemented with antipyretics, environmental cooling, and cooling blankets as indicated.

Hypoventilation in ICU patients with anti-NMDAR encephalitis may make it difficult to wean from mechanical ventilation. Ventilator weaning in these patients is further complicated by delirium, agitation, and movement disorders that may require heavy sedation. Placement of a tracheostomy and gastrostomy tube in the third week after diagnosis may improve patient safety and allow for less sedation and earlier rehabilitation.

Once medically feasible, it is paramount to begin a comprehensive rehabilitation program including physical, occupational, speech, and dysphagia therapy to improve long-term outcomes $(24,84)$. Functional decline in motor skills and cognition is common among patients with anti-NMDAR encephalitis and physical therapists with physiatrists should be engaged early in their management.

The available heterogeneous data impose methodological limitations for pooled analysis. Thus, one weakness of this review is the lack of statistical analysis for successful treatment 
or prognostic indicators. Our recommendations are limited to available low-grade evidence. However, this study provides a first step toward conducting randomized controlled trials to evaluate the efficacy of potential therapies.

\section{CONCLUSION}

Anti-N-methyl-D-aspartate receptor encephalitis is a commonly encountered adult and pediatric critical care diagnosis. Careful understanding of the clinical features of the disease, diagnosis, and treatment options may improve the care of these complex patients. Early rehabilitation and careful consideration for

\section{REFERENCES}

1. Vitaliani R, Mason W, Ances B, Zwerdling T, Jiang Z, Dalmau J. Paraneoplastic encephalitis, psychiatric symptoms, and hypoventilation in ovarian teratoma. Ann Neurol (2005) 58:594-604. doi:10.1002/ana.20614

2. Dalmau J, Tuzun E, Wu HY, Masjuan J, Rossi JE, Voloschin A, et al. Paraneoplastic anti-N-methyl-D-aspartate receptor encephalitis associated with ovarian teratoma. Ann Neurol (2007) 61:25-36. doi:10.1002/ana.21050

3. Gable MS, Sheriff H, Dalmau J, Tilley DH, Glaser CA. The frequency of autoimmune $\mathrm{N}$-methyl-D-aspartate receptor encephalitis surpasses that of individual viral etiologies in young individuals enrolled in the California Encephalitis Project. Clin Infect Dis (2012) 54:899-904. doi:10.1093/cid/ cir1038

4. Dalmau J, Gleichman AJ, Hughes EG, Rossi JE, Peng X, Lai M, et al. AntiNMDA-receptor encephalitis: case series and analysis of the effects of antibodies. Lancet Neurol (2008) 7:1091-8. doi:10.1016/S1474-4422(08)70224-2

5. Davies G, Irani SR, Coltart C, Ingle G, Amin Y, Taylor C, et al. Anti-N-methylD-aspartate receptor antibodies: a potentially treatable cause of encephalitis in the intensive care unit. Crit Care Med (2010) 38:679-82. doi:10.1097/CCM. 0b013e3181cb0968

6. Lafond P, Varvat J, Tardy B. N-methyl-D-aspartate limbic encephalitis: diagnosis should respect well-recognized criteria. Crit Care Med (2010) 38:1615. doi:10.1097/CCM.0b013e3181dd0993

7. Varvat J, Lafond P, Page Y, Coudrot M, Reynaud-Salard M, Tardy B. Acute psychiatric syndrome leading young patients to ICU: consider anti-NMDAreceptor antibodies. Anaesth Intensive Care (2010) 38:748-50.

8. Florance NR, Davis RL, Lam C, Szperka C, Zhou L, Ahmad S, et al. AntiN-methyl-D-aspartate receptor (NMDAR) encephalitis in children and adolescents. Ann Neurol (2009) 66:11-8. doi:10.1002/ana.21756

9. Poloni C, Korff CM, Ricotti V, King MD, Perez ER, Mayor-Dubois C, et al. Severe childhood encephalopathy with dyskinesia and prolonged cognitive disturbances: evidence for anti-N-methyl-D-aspartate receptor encephalitis. Dev Med Child Neurol (2010) 52:e78-82. doi:10.1111/j.1469-8749.2009. 03542.x

10. Raha S, Gadgil P, Sankhla C, Udani V. Nonparaneoplastic anti-N-methyl-Daspartate receptor encephalitis: a case series of four children. Pediatr Neurol (2012) 46:246-9. doi:10.1016/j.pediatrneurol.2012.01.012

11. Armangue T, Titulaer MJ, Málaga I, Bataller L, Gabilondo I, Graus F, et al. Pediatric anti-N-methyl-D-aspartate receptor encephalitis-clinical analysis and novel findings in a series of 20 patients. J Pediatr (2013) 162:850-6.e852. doi:10.1016/j.jpeds.2012.10.011

12. Howard CM, Kass JS, Bandi VDP, Guntupalli KK. Challenges in providing critical care for patients with anti-N-methyl-D-aspartate receptor encephalitis. Chest (2014) 145:1143-7. doi:10.1378/chest.13-1490

13. Byrne S, Walsh C, Hacohen Y, Muscal E, Jankovic J, Stocco A, et al. Earlier treatment of NMDAR antibody encephalitis in children results in a better outcome. Neurol Neuroimmunol Neuroinflamm (2015) 2:e130. doi:10.1212/ NXI.0000000000000130

14. Titulaer MJ, McCracken L, Gabilondo I, Armangué T, Glaser C, Iizuka T, et al. Treatment and prognostic factors for long-term outcome in patients with anti-NMDA receptor encephalitis: an observational cohort study. Lancet Neurol (2013) 12:157-65. doi:10.1016/S1474-4422(12)70310-1 tracheostomy and gastrostomy placement may further improve functional outcomes. Future studies investigating both pharmacologic approaches and non-pharmacologic interventions of autonomic dysfunction, movement disorders, and cardiac arrhythmias will be important in improving patient care and outcomes.

\section{AUTHOR CONTRIBUTIONS}

KR, JWC, JC, CF, NG, LW, LS, and DB all had direct involvement in the design, writing, and editing of this manuscript. KR performed the pooled analysis.

15. Byrne S, McCoy B, Lynch B, Webb D, King MD. Does early treatment improve outcomes in N-methyl-D-aspartate receptor encephalitis? Dev Med Child Neurol (2014) 56:794-6. doi:10.1111/dmcn.12411

16. Florance-Ryan N, Dalmau J. Update on anti-N-methyl-D-aspartate receptor encephalitis in children and adolescents. Curr Opin Pediatr (2010) 22:739-44. doi:10.1097/MOP.0b013e3283402d2f

17. Borlot F, Santos ML, Bandeira M, Liberalesso PB, Kok F, Löhr A Jr, et al. Anti$\mathrm{N}$-methyl D-aspartate receptor encephalitis in childhood. J Pediatr (Rio J) (2012) 88:275-8. doi:10.2223/JPED.2172

18. Byrne S, Jordan I, Redmond J. Prevalence and treatment of anti-NMDA receptor encephalitis. Lancet Neurol (2013) 12:424. doi:10.1016/ S1474-4422(13)70069-3

19. Cantarín-Extremera V, Duat-Rodríguez A, González-Gutiérrez-Solana L, López-Marín L, Armangue T. Clinical case of anti-N-methyl-D-aspartate receptor encephalitis in an 8-month-old patient with hyperkinetic movement disorder. Pediatr Neurol (2013) 48:400-2. doi:10.1016/j.pediatrneurol.2012.12.032

20. Casanova-Gracia N, Banzo-Arguis C, Sanz-Asin P, Zapata-Usabel M, JordanaVilanova N, Cortina-Lacambra MT. [Encephalitis associated to anti-NMDA receptor antibodies: a description of two cases in the child/youth population]. Rev Neurol (2012) 54:475-8.

21. Desena A, Graves D, Warnack W, Greenberg BM. Herpes simplex encephalitis as a potential cause of anti-N-methyl-D-aspartate receptor antibody encephalitis: report of 2 cases. JAMA Neurol (2014) 71:344-6. doi:10.1001/ jamaneurol.2013.4580

22. Gable MS, Gavali S, Radner A, Tilley DH, Lee B, Dyner L, et al. AntiNMDA receptor encephalitis: report of ten cases and comparison with viral encephalitis. Eur J Clin Microbiol Infect Dis (2009) 28:1421-9. doi:10.1007/ s10096-009-0799-0

23. Goldberg EM, Taub KS, Kessler SK, Abend NS. Anti-NMDA receptor encephalitis presenting with focal non-convulsive status epilepticus in a child. Neuropediatrics (2011) 42:188-90. doi:10.1055/s-0031-1295408

24. Houtrow AJ, Bhandal M, Pratini NR, Davidson L, Neufeld JA. The rehabilitation of children with anti-N-methyl-D-aspartate-receptor encephalitis: a case series. Am J Phys Med Rehabil (2012) 91:435-41. doi:10.1097/PHM. 0b013e3182465da6

25. Hung TY, Foo NH, Lai MC. Anti-N-methyl-d-aspartate receptor encephalitis. Pediatr Neonatol (2011) 52:361-4. doi:10.1016/j.pedneo.2011.08.012

26. Lin JJ, Lin KL, Hsia SH, Chou ML, Hung PC, Hsieh MY, et al. Anti$\mathrm{N}$-methyl-D-aspartate receptor encephalitis in Taiwan - a comparison between children and adults. Pediatr Neurol (2014) 50:574-80. doi:10.1016/j. pediatrneurol.2014.01.049

27. Kashyape P, Taylor E, Ng J, Krishnakumar D, Kirkham F, Whitney A. Successful treatment of two paediatric cases of anti-NMDA receptor encephalitis with cyclophosphamide: the need for early aggressive immunotherapy in tumour negative paediatric patients. Eur J Paediatr Neurol (2012) 16:74-8. doi:10.1016/j.ejpn.2011.07.005

28. Kuo YL, Tsai HF, Lai MC, Lin CH, Yang YK. Anti-NMDA receptor encephalitis with the initial presentation of psychotic mania. J Clin Neurosci (2012) 19:896-8. doi:10.1016/j.jocn.2011.10.006

29. Kurian M, Fluss J, Korff C. Anti-NMDA receptor encephalitis: the importance of early diagnosis and aggressive immunotherapy in tumor negative pediatric patients. EurJ Paediatr Neurol (2012) 16:764-5. doi:10.1016/j.ejpn.2012.03.004 
30. Lesher AP, Myers TJ, Tecklenburg F, Streck CJ. Anti-N-methyl-D-aspartate receptor encephalitis associated with an ovarian teratoma in an adolescent female. J Pediatr Surg (2010) 45:1550-3. doi:10.1016/j.jpedsurg.2010.04.002

31. Luca N, Daengsuwan T, Dalmau J, Jones K, deVeber G, Kobayashi J, et al. Anti-N-methyl-D-aspartate receptor encephalitis: a newly recognized inflammatory brain disease in children. Arthritis Rheum (2011) 63:2516-22. doi:10.1002/art.30437

32. Mann A, Machado NM, Liu N, Mazin AH, Silver K, Afzal KI. A multidisciplinary approach to the treatment of anti-NMDA-receptor antibody encephalitis: a case and review of the literature. J Neuropsychiatry Clin Neurosci (2012) 24:247-54. doi:10.1176/appi.neuropsych.11070151

33. Martin-Viota L, Garcia-Conde M, Solis-Reyes C, Duque-Fernandez MR, Lopez-Mendoza S. [Anti-NMDA receptor encephalitis in a 3-year-old girl with no associated pathology involving a tumour]. Rev Neurol (2012) 55:593-7.

34. Mirza MK, Pogoriler J, Paral K, Ananthanarayanan V, Mandal S, Mazin A, et al. Adjunct therapeutic plasma exchange for anti-N-methyl-D-aspartate receptor antibody encephalitis: a case report and review of literature. J Clin Apher (2011) 26:362-5. doi:10.1002/jca.20312

35. Pham HP, Daniel-Johnson JA, Stotler BA, Stephens H, Schwartz J. Therapeutic plasma exchange for the treatment of anti-NMDA receptor encephalitis. J Clin Apher (2011) 26:320-5. doi:10.1002/jca.20311

36. Sommeling C, Santens P. Anti-N-methyl-D-aspartate (anti-NMDA) receptor antibody encephalitis in a male adolescent with a large mediastinal teratoma. J Child Neurol (2014) 29:688-90. doi:10.1177/0883073813520499

37. Sonn TS, Merritt DF. Anti-NMDA-receptor encephalitis: an adolescent with an ovarian teratoma. J Pediatr Adolesc Gynecol (2010) 23:e141-4. doi:10.1016/j. jpag.2010.02.007

38. Verfaillie L, Bissay V, Vanderbruggen N, Van Eetvelde E, Honoré PM, Spapen H. An unusual case of acute psychosis in an adolescent. Acta Clin Belg (2013) 68:138-9. doi:10.2143/ACB.3252

39. Verhelst H, Verloo P, Dhondt K, De Paepe B, Menten B, Dalmau J, et al. Anti-NMDA-receptor encephalitis in a 3 year old patient with chromosome 6p21.32 microdeletion including the HLA cluster. Eur J Paediatr Neurol (2011) 15:163-6. doi:10.1016/j.ejpn.2010.07.004

40. Salvucci A, Devine IM, Hammond D, Sheth RD. Pediatric anti-NMDA (N-methyl D-aspartate) receptor encephalitis. Pediatr Neurol (2014) 50:507-10. doi:10.1016/j.pediatrneurol.2014.01.012

41. Scott O, Richer L, Forbes K, Sonnenberg L, Currie A, Eliyashevska M, et al. Anti-N-methyl-D-aspartate (NMDA) receptor encephalitis: an unusual cause of autistic regression in a toddler. J Child Neurol (2014) 29:691-4. doi:10.1177/0883073813501875

42. Shruthi TK, Shuba S, Rajakumar PS, Chitrambalam S. Anti-NMDA receptor encephalitis in an adolescent. Indian Pediatr (2014) 51:405-6.

43. Chakrabarty B, Tripathi M, Gulati S, Yoganathan S, Pandit AK, Sinha A, et al. Pediatric anti-N-methyl-D-aspartate (NMDA) receptor encephalitis: experience of a tertiary care teaching center from north India. J Child Neurol (2014) 29:1453-9. doi:10.1177/0883073813494474

44. Liu J, Wang D, Xiong Y, Liu B, Liu M. Anti-NMDAR encephalitis of 11 cases in China - detailed clinical, laboratory and imagiological description. Eur Neurol (2015) 74:73-8. doi:10.1159/000435953

45. Armangue T, Moris G, Cantarín-Extremera V, Conde CE, Rostasy K, Erro ME, et al. Autoimmune post-herpes simplex encephalitis of adults and teenagers. Neurology (2015) 85:1736-43. doi:10.1212/WNL.0000000000002125

46. Kramina S, Kevere L, Bezborodovs N, Purvina S, Rozentals G, Strautmanis J, et al. Acute psychosis due to non-paraneoplastic anti-NMDA-receptor encephalitis in a teenage girl: case report. Psych J (2015) 4:226-30. doi:10.1002/ pchj.121

47. Cleland N, Lieblich S, Schalling M, Rahm C. A 16-year-old girl with anti-NMDA-receptor encephalitis and family history of psychotic disorders. Acta Neuropsychiatr (2015) 27:375-9. doi:10.1017/neu.2015.32

48. Mechelhoff D, van Noort BM, Weschke B, Bachmann CJ, Wagner C, Pfeiffer E, et al. Anti-NMDA receptor encephalitis presenting as atypical anorexia nervosa: an adolescent case report. Eur Child Adolesc Psychiatry (2015) 24:1321-4. doi:10.1007/s00787-015-0682-8

49. Guan W, Fu Z, Zhang H, Jing L, Lu J, Zhang J, et al. Non-tumor-associated anti-N-methyl-D-aspartate (NMDA) receptor encephalitis in Chinese girls with positive anti-thyroid antibodies. JChild Neurol (2015) 30:1582-5. doi:10.1177/0883073815575365
50. Jones KC, Schwartz AC, Hermida AP, Kahn DA. A case of anti-NMDA receptor encephalitis treated with ECT. J Psychiatr Pract (2015) 21:374-80. doi:10.1097/PRA.0000000000000100

51. Lee A, Glick DB, Dinwiddie SH. Electroconvulsive therapy in a pediatric patient with malignant catatonia and paraneoplastic limbic encephalitis. J ECT (2006) 22:267-70. doi:10.1097/01.yct.0000244236.72049.9e

52. Wilson JE, Shuster J, Fuchs C. Anti-NMDA receptor encephalitis in a 14-year-old female presenting as malignant catatonia: medical and psychiatric approach to treatment. Psychosomatics (2013) 54(6):585-9. doi:10.1016/j. psym.2013.03.002

53. Wright S, Hacohen Y, Jacobson L, Agrawal S, Gupta R, Philip S, et al. $\mathrm{N}$-methyl-D-aspartate receptor antibody-mediated neurological disease: results of a UK-based surveillance study in children. Arch Dis Child (2015) 100:521-6. doi:10.1136/archdischild-2014-306795

54. Joseph K, Oliveira CR, Baltimore RS. A 14-year-old girl with slurred speech, aggressive behavior, and seizures. Pediatr Ann (2015) 44:236-7. doi:10.3928/00904481-20150611-05

55. Sands TT, Nash K, Tong S, Sullivan J. Focal seizures in children with anti-NMDA receptor antibody encephalitis. Epilepsy Res (2015) 112:31-6. doi:10.1016/j.eplepsyres.2015.02.010

56. Yushvayev-Cavalier Y, Nichter C, Ramirez-Zamora A. Possible autoimmune association between herpes simplex virus infection and subsequent anti-N-methyl-d-aspartate receptor encephalitis: a pediatric patient with abnormal movements. Pediatr Neurol (2015) 52:454-6. doi:10.1016/j. pediatrneurol.2014.10.011

57. Berg A, Byrne R, Coffey BJ. Neuroleptic malignant syndrome in a boy with NMDA receptor encephalitis. JChild Adolesc Psychopharmacol (2015) 25:368-71. doi:10.1089/cap.2015.29000.bjc

58. DeSena AD, Noland DK, Matevosyan K, King K, Phillips L, Qureshi SS, et al. Intravenous methylprednisolone versus therapeutic plasma exchange for treatment of anti-N-methyl-D-aspartate receptor antibody encephalitis: a retrospective review. J Clin Apher (2015) 30:212-6. doi:10.1002/jca.21363

59. Irani SR, Vincent A. NMDA receptor antibody encephalitis. Curr Neurol Neurosci Rep (2011) 11:298-304. doi:10.1007/s11910-011-0186-y

60. Granerod J, Ambrose HE, Davies NW, Clewley JP, Walsh AL, Morgan D, et al. Causes of encephalitis and differences in their clinical presentations in England: a multicentre, population-based prospective study. Lancet Infect Dis (2010) 10:835-44. doi:10.1016/S1473-3099(10)70222-X

61. Irani SR, Bera K, Waters P, Zuliani L, Maxwell S, Zandi MS, et al. N-methyl$\mathrm{D}$-aspartate antibody encephalitis: temporal progression of clinical and paraclinical observations in a predominantly non-paraneoplastic disorder of both sexes. Brain (2010) 133:1655-67. doi:10.1093/brain/awq113

62. Peery HE, Day GS, Doja A, Xia C, Fritzler MJ, Foster WG. Anti-NMDA receptor encephalitis in children: the disorder, its diagnosis, and treatment. Handb Clin Neurol (2013) 112:1229-33. doi:10.1016/B978-0-444-52910-7.00045-3

63. Dale RC, Irani SR, Brilot F, Pillai S, Webster R, Gill D, et al. N-methyl-Daspartate receptor antibodies in pediatric dyskinetic encephalitis lethargica. Ann Neurol (2009) 66:704-9. doi:10.1002/ana.21807

64. Lebas A, Husson B, Didelot A, Honnorat J, Tardieu M. Expanding spectrum of encephalitis with NMDA receptor antibodies in young children. JChild Neurol (2010) 25:742-5. doi:10.1177/0883073809343319

65. DuBray K, Anglemyer A, LaBeaud AD, Flori H, Bloch K, Joaquin KS, et al. Epidemiology, outcomes and predictors of recovery in childhood encephalitis: a hospital-based study. Pediatr Infect Dis J (2013) 32:839-44. doi:10.1097/ INF.0b013e318290614f

66. Peery HE, Day GS, Dunn S, Fritzler MJ, Prüss H, De Souza C, et al. AntiNMDA receptor encephalitis. The disorder, the diagnosis and the immunobiology. Autoimmun Rev (2012) 11:863-72. doi:10.1016/j.autrev.2012.03.001

67. Bseikri MR, Barton JR, Kulhanjian JA, Dalmau J, Cohen RA, Glaser CA, et al. Anti-N-methyl D-aspartate receptor encephalitis mimics viral encephalitis. Pediatr Infect Dis J (2012) 31:202-4. doi:10.1097/INF.0b013e31823d52eb

68. Moscato EH, Jain A, Peng X, Hughes EG, Dalmau J, Balice-Gordon RJ. Mechanisms underlying autoimmune synaptic encephalitis leading to disorders of memory, behavior and cognition: insights from molecular, cellular and synaptic studies. Eur J Neurosci (2010) 32:298-309. doi:10.1111/ j.1460-9568.2010.07349.x

69. Dalmau J, Lancaster E, Martinez-Hernandez E, Rosenfeld MR, BaliceGordon R. Clinical experience and laboratory investigations in patients with 
anti-NMDAR encephalitis. Lancet Neurol (2011) 10:63-74. doi:10.1016/ S1474-4422(10)70253-2

70. Hacohen Y, Singh R, Rossi M, Lang B, Hemingway C, Lim M, et al. Clinical relevance of voltage-gated potassium channel-complex antibodies in children. Neurology (2015) 85:967-75. doi:10.1212/WNL.0000000000001922

71. Hacohen Y, Wright S, Waters P, Agrawal S, Carr L, Cross H, et al. Paediatric autoimmune encephalopathies: clinical features, laboratory investigations and outcomes in patients with or without antibodies to known central nervous system autoantigens. J Neurol Neurosurg Psychiatry (2013) 84:748-55. doi:10.1136/jnnp-2012-303807

72. Kuppuswamy PS, Takala CR, Sola CL. Management of psychiatric symptoms in anti-NMDAR encephalitis: a case series, literature review and future directions. Gen Hosp Psychiatry (2014)36:388-91.doi:10.1016/j.genhosppsych.2014.02.010

73. Dhossche D, Fink M, Shorter E, Wachtel LE. Anti-NMDA receptor encephalitis versus pediatric catatonia. Am J Psychiatry (2011) 168:749-50. doi:10.1176/ appi.ajp.2011.11030471

74. Dhossche DM, Wachtel LE. Catatonia is hidden in plain sight among different pediatric disorders: a review article. Pediatr Neurol (2010) 43:307-15. doi:10.1016/j.pediatrneurol.2010.07.001

75. Reed MD, Blumer JL. Propofol bashing: the time to stop is now! Crit Care Med (1996) 24:175-6. doi:10.1097/00003246-199601000-00030

76. Reed MD, Yamashita TS, Marx CM, Myers CM, Blumer JL. A pharmacokinetically based propofol dosing strategy for sedation of the critically ill, mechanically ventilated pediatric patient. Crit Care Med (1996) 24:1473-81. doi:10.1097/00003246-199609000-00008

77. Bray R. Propofol infusion in children. Crit Care Med (2000) 28:2177-8. doi:10.1097/00003246-200006000-00115

78. Bray RJ. Propofol infusion for ICU sedation in children. Anaesthesia (2002) 57:521. doi:10.1046/j.1365-2044.2002.262633.x
79. Deem S. Intensive-care-unit-acquired muscle weakness. Respir Care (2006) 51:1042-52.

80. Lee M, Lawn N, Prentice D, Chan J. Anti-NMDA receptor encephalitis associated with ictal asystole. J Clin Neurosci (2011) 18:1716-8. doi:10.1016/j. jocn.2011.03.024

81. Millichap JJ, Goldstein JL, Laux LC, Nordli DR Jr, Stack CV, Wainwright MS. Ictal asystole and anti-N-methyl-D-aspartate receptor antibody encephalitis. Pediatrics (2011) 127:e781-6. doi:10.1542/peds.2010-2080

82. Sadaka F, Naydenov SK, Ponzillo JJ. Theophylline for bradycardia secondary to cervical spinal cord injury. Neurocrit Care (2010) 13:389-92. doi:10.1007/ s12028-010-9454-y

83. Day GS, High SM, Cot B, Tang-Wai DF. Anti-NMDA-receptor encephalitis: case report and literature review of an under-recognized condition. J Gen Intern Med (2011) 26:811-6. doi:10.1007/s11606-011-1641-9

84. Bradley L. Rehabilitation following anti-NMDA encephalitis. Brain Inj (2015) 29:785-8. doi:10.3109/02699052.2015.1004741

Conflict of Interest Statement: The authors declare that the research was conducted in the absence of any commercial or financial relationships that could be construed as a potential conflict of interest.

Copyright (C) 2017 Remy, Custer, Cappell, Foster, Garber, Walker, Simon and Bagdure. This is an open-access article distributed under the terms of the Creative Commons Attribution License (CC BY). The use, distribution or reproduction in other forums is permitted, provided the original author(s) or licensor are credited and that the original publication in this journal is cited, in accordance with accepted academic practice. No use, distribution or reproduction is permitted which does not comply with these terms. 